Małysa-Sulińska, K., Kawecka, A. (2020). Zasiłek celowy na zaspokojenie niezbędnej potrzeby bytowej jako forma pomocy społecznej przeciwdziałająca wykluczeniu społecznemu. W: I. Lipowicz, M. Małecka Łyszczek (red.). Ekonomia Społeczna. Wykluczenie społeczne (s. 35-47). Kraków: Uniwersytet Ekonomiczny w Krakowie. https://doi.org/10.15678/ES.2020.1.04

\title{
Zasiłek celowy na zaspokojenie niezbędnej potrzeby bytowej jako forma pomocy społecznej przeciwdziałająca wykluczeniu społecznemu
}

\author{
Katarzyna Małysa-Sulińska, Anna Kawecka
}

Streszczenie: Celem systemu pomocy społecznej jest wsparcie jednostki, a przez to przeciwdziałanie wykluczeniu społecznemu. Regulacje normatywne w tym zakresie ujęte są w szczególności w ustawie z dnia 12 marca 2004 r. o pomocy społecznej, która określa między innymi rodzaje świadczeń z pomocy społecznej oraz zasady i tryb ich udzielania, a jednym z tych świadczeń jest - przyznawany na zaspokojenie niezbędnej potrzeby bytowej - zasiłek celowy. W artykule podjęto rozważania czy zasiłek celowy jest świadczeniem stanowiącym skuteczne narzędzie przeciwdziałania wykluczeniu społecznemu. W związku z tym przedstawiono i poddano analizie regulacje normatywne determinujące przyznanie i kształt tego świadczenia. Analiza ta prowadzi do wniosku, że funkcjonująca w polskim systemie prawnym instytucja zasiłku celowego na zaspokojenie niezbędnej potrzeby bytowej może być postrzegana jako skuteczny mechanizm przeciwdziałający wykluczeniu społecznemu.

Słowa kluczowe: pomoc społeczna, wsparcie finansowe obywateli przez państwo, przeciwdziałanie ubóstwu, zasiłek celowy na zaspokojenie niezbędnej potrzeby bytowej, świadczenie o charakterze pieniężnym

Kody JEL: $\mathrm{J} 65 ; \mathrm{H} 55$

\section{Wprowadzenie}

Polski ustawodawca deklaruje potrzebę istnienia systemu pomocy społecznej mającego na celu: zapewnienie osobom i rodzinom wsparcia w przezwyciężeniu trudnej sytuacji, jakiej nie są w stanie pokonać wykorzystując własne uprawnienia, zasoby i możliwości, umożliwienie osobom i rodzinom życie w warunkach odpowiadających godności człowieka, zapewnienie dochodu na poziomie interwencji socjalnej dla osób nie posiadających dochodu lub o niskich dochodach, w wieku poprodukcyjnym i osób niepełnosprawnych, zapewnienie profesjonalnej pomocy rodzinom dotkniętym skutkami patologii społecznej, doprowadzenie osoby i rodziny otrzymujące pomoc społeczną do życiowego usamodzielniania, integrowanie ze środowiskiem osób wykluczonych społecznie, a także stworzenie sieci usług socjalnych adekwatnych do potrzeb w tym zakresie (zob. Uzasadnienie, 2003; Sierpowska, 2008, s. 7 i nast.). Regulacje normatywne w tym zakresie ujęte są w szczególności w ustawie z dnia 12 marca 2004 r. 
o pomocy społecznej (w dalszej części przywoływana jako u.p.s.), która określa między innymi rodzaje świadczeń z pomocy społecznej oraz zasady i tryb ich udzielania (u.p.s., art. 1).

Jedną z form pomocy społecznej jest przyznawanie i wypłacanie świadczeń przewidzianych w u.p.s. (art. 15 ust. 1 pkt 1), a do świadczeń pieniężnych, o których mowa w tej ustawie zalicza się między innymi zasiłek celowy (tamże, art. 36 pkt 1 lit.). Zauważenia przy tym wymaga, że ustawodawca przewiduje wyjątek od zasady pieniężnego charakteru tego świadczenia, wskazując, że przedmiotowy zasiłek może być przyznany w formie - będącego świadczeniem niepieniężnym (tamże, art. 36 pkt 2 lit b) - biletu kredytowanego (tamże, art. 39 ust. 4). Zasiłek celowy może być przyznany w celu zaspokojenia niezbędnej potrzeby bytowej (tamże, art. 39 ust. 1), a w szczególności na pokrycie części lub całości kosztów zakupu żywności, leków i leczenia, opału, odzieży, niezbędnych przedmiotów użytku domowego, drobnych remontów i napraw w mieszkaniu, a także kosztów pogrzebu (tamże, art. 39 ust. 2). Nadto - osobom bezdomnym i innym osobom niemającym dochodu oraz możliwości uzyskania świadczeń na podstawie przepisów o świadczeniach opieki zdrowotnej finansowanych ze środków publicznych - zasiłek celowy może być przyznany na pokrycie części lub całości wydatków na świadczenia zdrowotne (tamże, art. 39 ust. 3).

W świetle Konstytucji uzasadnione jest przyjmowanie w ustawodawstwie zwykłym ochrony nakierowanej na ochronę godności człowieka przed jego wykluczeniem społecznym (Wyrok TK z 22.05.2013, s. 42). Polityka państwa realizowana w formie pomocy społecznej ma przeciwdziałać między innymi ubóstwu tak jednostki, jak i rodziny, a w związku z tym - związanemu z ubóstwem - wykluczeniu społecznemu. Podkreślenia wymaga przy tym, że wykluczenie społeczne nie jest tożsame z ubóstwem, choć ubóstwo jest tym czynnikiem, który najczęściej powoduje wyłączenie jednostki z uczestniczenia w życiu społecznym (Golinowska i Broda-Wysocki, 2005, s. 42). Wykluczenie obejmuje bowiem wszystkie te przypadki, gdy dana osoba nie może - z uwagi nie na wewnętrzne przekonanie, ale czynniki znajdujące się poza jej kontrolą- uczestniczyć w określonym obszarze życia społecznego (np. gospodarczego, kulturowego, politycznego, zawodowego) (Małecka-Łyszczek, 2017, s. 411). Jako przykład - determinowanego ubóstwem - wykluczenia społecznego można wskazać brak możliwości pobierania edukacji na wysokim poziomie z uwagi na niedostępność pewnych dóbr np. komputera, książek czy innych materiałów niezbędnych do jej prawidłowego prowadzenia.

Rozważenia wymaga zatem, czy zasiłek celowy jest świadczeniem stanowiącym skuteczne narzędzie przeciwdziałania wykluczeniu społecznemu. Celem niniejszego tekstu jest więc przedstawienie i analiza regulacji normatywnych determinujących przyznanie i kształt tego świadczenia, które - w założeniu ustawodawcy - stanowić ma jedną z form wsparcia osób w trudnej sytuacji, jakiej nie są w stanie pokonać wykorzystując własne zasoby i możliwości, stanowiąc jednocześnie gwarancje życia tych osób w warunkach odpowiadających godności człowieka. Godność człowieka jako wartość i zasada konstytucyjna, ale i odrębne prawo podmiotowe, zakłada okazywanie przez władzę szacunku, respektu dla człowieczeństwa, jak i aktywne działanie na rzecz godności człowieka samej władzy publicznej, a to ustawodawczej, wykonawczej i sądowniczej. Jednocześnie godność człowieka jest nadal obdarzana zbyt małą uwagą, traktowana bardziej jako uroczysta deklaracja niemająca praktycznego przełożenia na codzienne prawa i obowiązki milionów ludzi (Lipowicz, 2013, s. 42). Dlatego w treści artykułu przedstawiono postępowanie w sprawie przyznania zasiłku celowego na zaspokojenie niezbędnej potrzeby bytowej, zwracając w szczególności uwagę na formy jego wszczęcia, czynności podejmowane w toku tego postępowania, a także rozstrzygnięcie jakie może zostać podjęte w sprawie. Analiza tych przepisów, poparta stosownym orzecznictwem, umożliwia 
bowiem odpowiedź na pytanie czy funkcjonująca w polskim systemie prawnym instytucja zasiłku celowego na zaspokojenie niezbędnej potrzeby bytowej w praktyce jest skutecznym narzędziem przeciwdziałania wykluczeniu społecznemu.

\section{Podjęcie postępowania w sprawie przyznania zasiłku celowego na zaspokojenie niezbędnej potrzeby bytowej}

Zgodnie z regulacją ujętą w przepisach u.p.s. świadczenia z pomocy społecznej są udzielane na wniosek osoby zainteresowanej, jej przedstawiciela ustawowego albo innej osoby, za zgodą osoby zainteresowanej lub jej przedstawiciela ustawowego (u.p.s., art. 102 ust. 1), przy czym pomoc społeczna może być udzielana również z urzędu (tamże, art. 102 ust. 2). Oznacza to, że postępowanie w sprawie przyznania zasiłku celowego na zaspokojenie niezbędnej potrzeby bytowej może być podjęte albo na wniosek, albo z urzędu.

Wszczęcie postępowania w sprawie przyznania zasiłku celowego na zaspokojenie niezbędnej potrzeby bytowej może zatem nastąpić na wniosek osoby zainteresowanej czyli osoby fizycznej, która wymaga wsparcia w ramach systemu pomocy społecznej. Zgodnie z ogólnymi regulacjami kodeksowymi osoba taka może samodzielnie występować w przedmiotowym postępowaniu wyłącznie wówczas, gdy ma zdolność do czynności prawnych (Wróbel, 2020, s. 247; Romańska, 2015, s. 225 i n; Matan, 2010, s. 311 i nast.). W innym przypadku w jej imieniu występuje przedstawiciel ustawowy (Wróbel, 2020, s. 248; Romańska, 2015, s. 225 i nast.; Matan, 2010, s. 329 i nast.). Dopuszczalne jest także, aby wniosek w sprawie przyznania zasiłku celowego na zaspokojenie niezbędnej potrzeby bytowej złożył pełnomocnik strony (Wróbel, 2020, s. 272 i nast.; Romańska, 2015, s. 225 i nast.; Matan, 2010, s. 385 i nast.). Wniosek taki może być wniesiony w każdej z form wskazanych w przepisach ustawy z dnia 14 czerwca 1960 r. Kodeks postępowania administracyjnego (k.p.a., art. 63, par. 1). Oznacza to, że dopuszczalne jest wniesienie takiego wniosku pisemnie, telegraficznie, za pomocą telefaksu lub ustnie do protokołu, a także za pomocą innych środków komunikacji elektronicznej przez elektroniczną skrzynkę podawczą organu administracji publicznej utworzoną na podstawie ustawy z dnia 17 lutego 2005 r. o informatyzacji działalności podmiotów realizujących zadania publiczne. W przepisach u.p.s. nie ujęto wymagań szczególnych względem wniosku o przyznanie zasiłku celowego. Oznacza to, że wniosek taki podlega regulacji ogólnej ujętej w k.p.a., a w związku z tym powinien zawierać wskazanie osoby, od której pochodzi, jej adres i żądanie (k.p.a., art. 63, par. 2). Poprzez wskazanie osoby, od której wniosek pochodzi należy rozumieć podanie jej imienia i nazwiska, a pod pojęciem adresu osoby wnoszącej rozumieć należy adres zamieszkania, pobytu bądź do korespondencji (Wyrok WSA w Warszawie z 26.09.2017). W orzecznictwie wskazuje się bowiem, iż adresem wnioskodawcy jest miejsce, w którym będzie możliwe, zgodnie z jego wolą, doręczenie pism urzędowych (Wyrok WSA w Gdańsku z 22.09.2010). Treść wniosku o przyznanie świadczenia z zakresu pomocy społecznej stanowi podstawę ustalenia, jakiego świadczenia dotyczy żądanie. Na właściwym organie ciąży zatem obowiązek stwierdzenia jaką i czyją niezbędną potrzebę bytową ma zaspakajać wnioskowany zasiłek celowy (Wyrok WSA w Poznaniu z 29.05.2018). Wniosek wyznacza bowiem granice sprawy podlegającej rozpoznaniu i rozstrzygnięciu w drodze decyzji. Konsekwencją wszczęcia postępowania na wniosek jest więc związanie organu administracyjnego zakresem zgłoszonego żądania, co oznacza, że nie może on samodzielnie ustalić jego treści, ani też prowadzić postępowania administracyjnego i wydać rozstrzygnięcia w innym przedmiocie czy zakresie, niż wynika to z treści złożonego wniosku (Wyrok WSA we Wrocławiu z 14.05.2019). Podkreślić wymaga też, 
że organ właściwy w sprawie nie jest również uprawniony do narzucania wnioskodawcy treści żądania niezgodnego z jego wolą (Wyrok WSA w Opolu z 13.05.2014). Nadto wniosek wniesiony pisemnie powinien zostać podpisany przez wnoszącego (k.p.a., art. 63, par. 3 zd. 1). Przez podpis rozumie się przy tym napisany lub uwierzytelniony znak ręczny i tylko taki może być kwalifikowany jako spełniający wymagania formalne co do treści podania. Nie może więc być on zastąpiony podpisem mechanicznym (Wyrok WSA w Warszawie z 23.03.2017; Wyrok WSA w Warszawie z 11.08.2011; Wyrok WSA w Łodzi z 23.10.2008). Gdy wniosek składa osoba, która nie może lub nie umie złożyć podpisu, podanie podpisuje za nią inna osoba przez nią upoważniona, czyniąc o tym wzmiankę obok podpisu (k.p.a., art. 63, par. 3 zd. 2). Natomiast wniosek o przyznanie zasiłku celowego wniesiony w formie dokumentu elektronicznego - poza wskazanymi powyżej wymaganiami określonymi w art. 63 par. 2 k.p.a. - powinien być opatrzony kwalifikowanym podpisem elektronicznym, podpisem zaufanym albo podpisem osobistym, lub uwierzytelniany w sposób zapewniający możliwość potwierdzenia pochodzenia i integralności weryfikowanych danych w postaci elektronicznej (k.p.a., art. 63, par. 3a, pkt 1), a nadto zawierać adres elektroniczny wnoszącego (k.p.a., art. 63, par. 3a pkt 3).Wymóg złożenia podpisu przez wnioskodawcę obejmuje również przypadki, gdy wniosek o przyznanie zasiłku celowego został złożony ustnie do protokołu, przy czym w takim przypadku protokół powinien nadto zostać podpisany przez pracownika, który go sporządził (k.p.a., art. 63, par. 3a zd. 1). Jeśli zaś wniosek o przyznanie zasiłku celowego jest składany telegraficznie lub za pomocą telefaksu brak jest uzasadnienia dla kierowania pod adresem wnioskodawcy obowiązku jego podpisania (Wróbel, 2020, s. 381 i nast.; Romańska, 2015, s. 448; Łaszczyca, 2010, s. 529).

Postępowanie w sprawie przyznania zasiłku celowego na zaspokojenie niezbędnej potrzeby bytowej może zostać zainicjowane również na wniosek innej osoby czyli dowolnej osoby fizycznej, a to np.: pracownika socjalnego, nauczyciela, lekarza, sąsiada. Może to nastąpić jednak wyłącznie za zgodą osoby zainteresowanej lub jej przedstawiciela ustawowego, przy czym zgoda taka powinna być wyrażona w sposób jasny i jednoznaczny, a nie dorozumiany i powinna być utrwalona w aktach postępowania (Nitecki, 2012, s. 152). Wskazuje się przy tym, że postępowanie takie jest wszczętym na wniosek, a nie z urzędu (Sierpowska, 2014, s. 408 i nast.). Podkreślenia wymaga jednak, że osoba trzecia, która zainicjowała postępowanie w sprawie przyznania zasiłku celowego nie zyskuje statusu strony w tym postępowaniu, gdyż z żądaniem wszczęcia postępowania nie można utożsamiać interesu prawnego, a stroną - jak wynika z regulacji art. 28 k.p.a. - jest ten, czyjego interesu prawnego lub obowiązku dotyczy postępowanie albo kto żąda czynności organu ze względu na swój interes prawny lub obowiązek. W orzecznictwie sądowoadministracyjnym podnosi się jednak, że odformalizowane działanie tzw. innej osoby w imieniu zainteresowanego odnosi się do całości postępowania prowadzonego z jej wniosku, co oznacza, że obejmuje również postępowanie odwoławcze w sprawie przyznania zasiłku celowego (Wyrok WSA w Gliwicach z 22.07.2014). Prezentowane jest również stanowisko przeciwne, a to takie, że osoba trzecia ma tytuł do występowania we własnym imieniu na rzecz strony, lecz wyłącznie w początkowym stadium tego postępowania czyli podczas jego wszczynania (Maciejko, 2013, s. 362).

Nadto postępowanie w sprawie zasiłku celowego na zaspokojenie niezbędnej potrzeby bytowej może zostać podjęte z urzędu, co oznacza, że jego wszczęcie następuje w wyniku własnej inicjatywy właściwego organu (k.p.a., art. 61 par. 2). Podjęcie postępowania w sprawie stanowi wówczas konsekwencję powzięcia przez organ informacji o takim stanie faktycznym, który uzasadnia wydanie rozstrzygnięcia w sprawie przyznania przedmiotowego świadczenia. Wszczęcie postępowania z urzędu dotyczy w szczególności przypadków, gdy osoba wyma- 
gająca wsparcia z uwagi na swoją nieporadność społeczną, czy też nieznajomość procedur i przepisów prawa sama nie jest zdolna zainicjować postępowania (Matan, 2003, s. 477 i nast.; Knysiak-Molczyk, 2015, s. 245; Kędziora, 2008, s. 173). W orzecznictwie sądowym wskazuje się, że udzielenie pomocy z urzędu powinno obejmować w szczególności te przypadki, gdy osoba ubiegająca się o jedno świadczenie nie spełnia wymogów formalnych do jego otrzymania, a spełnia warunki do uzyskania innego świadczenia (Wyrok WSA w Lublinie z 6.03.2018). Podjęcie postępowania z urzędu może być również konsekwencją zgłoszenia właściwemu organowi potrzeby bytowej w formie innej niż - uregulowane w przepisach prawa - złożenie wniosku. W literaturze przedmiotu podnosi się bowiem, że nie jest dopuszczalne telefoniczne wniesienie podania, nawet w sytuacji niecierpiącej zwłoki ze względu na ważny interes wnoszącego (Wróbel, 2020, s. 381). Mając na uwadze powyższe wskazać należy, iż w praktyce działania organów realizujących zadania z zakresu pomocy społecznej zdarza się, że konieczność przyznania zasiłku celowego zgłaszana jest telefonicznie. Podmioty zainteresowane przyznaniem zasiłku celowego są bowiem często osobami chorymi bądź mającymi problemy z poruszaniem się. W takim przypadku - co dotyczy również zgłoszeń odebranych w formie e-maila - właściwy organ winien rozważyć zasadność wszczęcia z urzędu postępowania w sprawie przyznania zasiłku celowego na zaspokojenie niezbędnej potrzeby bytowej.

Zgodnie z ogólną regulacją kodeksową organ administracji publicznej, który z urzędu podjął postępowanie w sprawie, obowiązany jest uzyskać na to zgodę strony w toku postępowania, a w razie jej nieuzyskania - postępowanie umorzyć (k.p.a., art. 61, par. 2). W przypadku podjętych z urzędu postępowań w sprawie przyznania zasiłku celowego na zaspokojenie niezbędnej potrzeby bytowej zgoda taka udzielana jest zazwyczaj przy okazji - przeprowadzanego w toku tego postępowania - wywiadu środowiskowego. Dopuszczenie wszczęcia z urzędu przedmiotowego postępowania nie może oznaczać bowiem, że będzie ono prowadzone wbrew woli strony, nawet wówczas, gdy obiektywnie objęcie osoby pomocą ewidentnie jest potrzebne.

\section{Czynności podejmowane w toku postępowania w sprawie przyznania zasiłku celowego na zaspokojenie niezbędnej potrzeby bytowej}

Prawo do świadczeń pieniężnych z pomocy społecznej, w tym również zasiłku celowego na zaspokojenie niezbędnej potrzeby bytowej, przysługuje - co do zasady - w przypadku spełnienia kryterium dochodowego określonego w przepisach z zakresu pomocy społecznej (Stopka, 2017, s. 116; Sierpowska, 2014, s. 91 i nast.; Maciejko, 2013, s. 80; Lisowski, 2019, s. 37 i nast.), przy jednoczesnym wystąpieniu co najmniej jednego z powodów wymienionych w art. 7 pkt 2-15 u.p.s. lub innych okoliczności uzasadniających udzielenie pomocy społecznej (u.p.s., art. 8, ust. 1). Podkreślenia wymaga przy tym, że zasadą jest, iż rozstrzygnięcie w przedmiocie przyznania lub odmowy przyznania świadczenia z pomocy społecznej wydaje się po przeprowadzeniu rodzinnego wywiadu środowiskowego. Wyjątek w tym zakresie obejmuje decyzje o odmowie przyznania biletu kredytowanego oraz - opisane w art. 5a - decyzje w sprawach cudzoziemców (u.p.s, art. 106, ust. 4).

Zasadą jest zatem, że w toku przedmiotowego postępowania obligatoryjnie przeprowadza się rodzinny wywiad środowiskowy (Wyrok WSA w Łodzi z 11.06.2019; Wyrok WSA w Kielcach z 19.09.2018), którego celem jest ustalenie sytuacji osobistej, rodzinnej, dochodowej i majątkowej osoby, której potrzeba bytowa ma zostać zaspokojona poprzez przyznanie zasiłku celowego (u.p.s., art. 107, ust. 1). Ustalenia w tym zakresie mają bowiem zasadnicze znaczenie dla możliwości pozytywnego rozstrzygnięcia w zakresie przyznania zasiłku celowego (Wyrok WSA 
w Gorzowie Wielkopolskim z 20.11.2019). Rodzinny wywiad środowiskowy - co do zasady - jest podstawowym dowodem w sprawie o przyznanie zasiłku celowego na zaspokojenie niezbędnej potrzeby bytowej, a osoba zainteresowana powinna współdziałać z organem przy jego sporządzaniu (Wyrok WSA w Szczecinie z 24.10.2019). W oparciu o ustalenia poczynione w jego trakcie dokonywana jest bowiem analiza i ocena sytuacji osoby, której potrzeba bytowa ma zostać zaspokojona poprzez przyznanie zasiłku celowego, a nadto formułowane są wnioski odnośnie koniecznej pomocy, które są podstawą rozstrzygnięcia sprawy (Wyrok WSA w Kielcach z 22.01.2020).

Rodzinny wywiad środowiskowy przeprowadza się w terminie 14 dni roboczych od powzięcia wiadomości o konieczności jego przeprowadzenia (Rozporządzenie Ministra Rodziny..., 2016, par. 2, ust.1; dalej jako r.w.ś.), przy czym w sprawach niecierpiących zwłoki wywiad przeprowadza się niezwłocznie, nie później niż w terminie 2 dni roboczych od powzięcia wiadomości o potrzebie przyznania świadczenia z pomocy społecznej (r.w.ś, par. 2, ust. 2). Podkreślenia wymaga przy tym, że pracownicy socjalni nie muszą zapowiadać przeprowadzenia wywiadu środowiskowego, gdyż tylko nieobecność osoby, której ma zostać przyznany zasiłek celowy w miejscu zamieszkania uzasadnia zawiadomienie o terminie jego przeprowadzenia (Wyrok WSA we Wrocławiu z 21.05.2019). Zgodnie z przepisami wywiad ten przeprowadza się bowiem w miejscu zamieszkania lub pobytu osoby, której potrzeba bytowa ma zostać zaspokojona poprzez przyznanie zasiłku celowego (r.w.ś., par. 2, ust. 3). Oznacza to, że rodzinny wywiad środowiskowy nie może zostać sporządzony w dowolnym miejscu, a to np. w galerii handlowej. Przez miejsce zamieszkania należy bowiem w tym przypadku rozumieć nie tylko daną miejscowość, ale również konkretny budynek i lokal mieszkalny (Wyrok WSA we Wrocławiu z 14.06.2019a, 14.06.2019b; Wyrok WSA we Wrocławiu, 22.02.2019a, 22.02.2019b). Zaznaczenia wymaga również, iż w przypadku konieczności przeprowadzenia rodzinnego wywiadu środowiskowego z osobą ubezwłasnowolnioną, wywiad taki przeprowadza się z jej opiekunem prawnym albo kuratorem, w obecności osoby ubezwłasnowolnionej i w miejscu jej przebywania (r.w.ś, par. 5).

Rodzinny wywiad środowiskowy przeprowadza pracownik socjalny po okazaniu legitymacji, przy czym może to czynić również na potrzeby jednostki organizacyjnej pomocy społecznej z terenu innej gminy (u.p.s., art. 107, ust. 3). Zauważenia wymaga, że przy przeprowadzaniu rodzinnego wywiadu środowiskowego może uczestniczyć drugi pracownik socjalny, a nadto wywiad ten może odbywać się w asyście funkcjonariusza Policji (u.p.s., art. 107, ust 3a). W przypadku gdy osoba ubiegająca się o przyznanie świadczenia przebywa w zakładzie leczniczym, w rozumieniu ustawy z dnia 15 kwietnia 2011 r. o działalności leczniczej, wywiad może przeprowadzić natomiast albo pracownik socjalny zatrudniony w tym zakładzie, albo pracownik socjalny ośrodka pomocy społecznej (r.w.ś., par. 6). Jeśli zaś osoba, u której ma być przeprowadzona aktualizacja wywiadu', przebywa w domu pomocy społecznej, wywiad może przeprowadzić pracownik socjalny tego domu (r.w.ś., par. 8).

Osoba, której ma zostać przyznany zasiłek celowy jest zobligowana umożliwić przeprowadzenie rodzinnego wywiadu środowiskowego. Niewyrażenie zgody na jego przeprowadzenie przez osobę ubiegającą się o świadczenie z pomocy społecznej stanowi bowiem podstawę do odmowy przyznania tego świadczenia (u.p.s., art. 107, ust. 4a). Jak wskazuje się w orzecznictwie sądowoadministracyjnym wywiad ten jest nieodzownym elementem postępowania prowa-

1 Aktualizację rodzinnego wywiadu środowiskowego sporządza się - jak wskazano w art. 107 ust. 4 zd. 1 u.p.s. - w przypadku ubiegania się o przyznanie świadczenia z pomocy społecznej po raz kolejny, a także gdy nastąpiła zmiana danych zawartych w wywiadzie. 
dzącego do wydania decyzji przyznającej lub odmawiającej przyznania świadczenia z pomocy społecznej. Brak możliwości jego przeprowadzenia uniemożliwia bowiem właściwemu organowi dokonania oceny rzeczywistej sytuacji majątkowej, rodzinnej i bytowej osoby ubiegającej się o świadczenie. Ta obligatoryjna forma postępowania wyjaśniającego wymaga zatem od strony szczególnej aktywności, gdyż - z uwagi na charakter ustaleń odnoszących się do sfery ściśle osobistej - nie można jej zastąpić innymi środkami dowodowymi (Wyrok NSA z 7.03.2017; Wyrok NSA z 19.12.2016; Wyrok WSA w Poznaniu z 2.10.2019; Wyrok WSA w Łodzi z 20.06.2018; Wyrok WSA w Gdańsku z 12.04.2018).

Formularz rodzinnego wywiadu środowiskowego stanowi szczególną formę protokołu, o którym mowa w art. 67 par. 1 k.p.a. i tylko wtedy może być zaliczony do materiału dowodowego stanowiącego podstawę rozstrzygnięcia, gdy odpowiada wymogom przepisów prawa (Wyrok NSA z 23.03.2017). Mając na uwadze powyższe wskazać należy, że kwestionariusz rodzinnego wywiadu środowiskowego - jak wskazano w art. 107 ust. 5e u.p.s. - wypełnia się w postaci papierowej lub elektronicznej za pomocą systemu teleinformatycznego udostępnianego przez ministra właściwego do spraw zabezpieczenia społecznego. Podkreślić trzeba, że pracownik socjalny przeprowadzający rodzinny wywiad środowiskowy może domagać się od osoby ubiegającej się o pomoc złożenia oświadczenia o dochodach i stanie majątkowym, przy czym odmowa złożenia oświadczenia jest podstawą wydania decyzji o odmowie przyznania świadczenia (u.p.s., art. 107 ust. 5). Ustawodawca zakreślił równocześnie katalog dokumentów, w oparciu o które ustala się sytuację osobistą, rodzinną, dochodową i majątkową osoby, której niezbędną potrzebę bytową ma zaspokoić zasiłek celowy, a zostały one wskazane w art. 107 ust. 5b u.p.s. Zauważenia wymaga przy tym, że jeżeli okoliczności sprawy, mające wpływ na prawo do świadczeń, wymagają potwierdzenia innym - nieujętym w art. 107 ust. 5b u.p.s. oświadczeniem lub dokumentem, można domagać się takiego oświadczenia lub dokumentu. Podkreślić trzeba, że w aktach sprawy zamiast oryginałów można pozostawić - poświadczone za zgodność z oryginałem przez pracownika socjalnego przeprowadzającego wywiad - kopie dokumentów, o których mowa w art. 107 ust. 5b u.p.s., z wyjątkiem dowodu tożsamości, którego kopii nie wykonuje się (r.w.ś, par. 12, ust. 1). Wskazane powyżej dokumenty mogą być składane również w wersji elektronicznej (tamże, par. 12, ust. 2). W przypadku, gdy o przyznanie świadczenia ubiega się osoba, do której mają zastosowanie przepisy ustawy z dnia 19 sierpnia 1994 r. o ochronie zdrowia psychicznego, a z uwagi na stan jej zdrowia nie można uzyskać podczas rodzinnego wywiadu środowiskowego wymaganych informacji lub dokumentów, pracownik socjalny odnotowuje ten fakt w kwestionariuszu wywiadu (r.w.ś., par. 4).

Zgodnie z obowiązującym uregulowaniem normatywnym pracownik socjalny, przeprowadzając rodzinny wywiad środowiskowy, bierze pod uwagę indywidualne cechy, sytuację osobistą, rodzinną, dochodową i majątkową osoby samotnie gospodarującej lub osób w rodzinie, mogące mieć wpływ na rodzaj i zakres przyznawanej im pomocy (r.w.ś., par. 2, ust. 4). Nadto w ramach przeprowadzonego wywiadu pracownik socjalny dokonuje analizy i oceny sytuacji danej osoby lub rodziny i formułuje wnioski z nich wynikające, stanowiące podstawę planowania pomocy (tamże, par. 2, ust. 5). Oznacza to, że ustalenia poczynione przez pracownika socjalnego w trakcie przeprowadzania rodzinnego wywiadu środowiskowego mają umożliwić podjęcie rozstrzygnięcia w sprawie zarówno w zakresie możliwości przyznania wnioskowanego świadczenia, jak i jego wysokości. Wywiad środowiskowy w miejscu zamieszkania lub pobytu osoby, której potrzeba bytowa ma zostać zaspokojona poprzez przyznanie zasiłku celowego, ma stwarzać pracownikowi socjalnemu możliwość realnej - opartej o własne spostrzeżenia, a nie wyłącznie na podstawie deklaracji tej osoby oraz przedstawionych przez nią dokumen- 
tów na temat zgromadzonego majątku czy uzyskiwanych dochodów - oceny sytuacji bytowej tej osoby, w tym także jej poziomu życia (Wyrok WSA we Wrocławiu z 14.06.2019c; Wyrok WSA we Wrocławiu z 22.02.2019b).

Podkreślenia wymaga, że postępowanie w sprawie ustalenia prawa do zasiłku celowego oparte jest na zasadzie oficjalności, a prowadzący je organ jest zobowiązany do wyczerpującego zebrania, a następnie rozpatrzenia materiału dowodowego i rozstrzygnięcia sprawy. Prowadząc postępowanie dowodowe organ dysponuje instrumentami pozwalającymi na weryfikację twierdzeń zawartych w oświadczeniach strony, a nadto ma możliwość przeprowadzania własnych dowodów na potrzeby rozstrzygnięcia sprawy. Jako dowód w sprawie należy bowiem dopuścić wszystko co może przyczynić się do jej wyjaśnienia i nie jest sprzeczne z prawem, a w szczególności dokumenty, zeznania świadków czy opinie biegłych (k.p.a., art. 75, par. 1). Należy zwrócić uwagę, że - co do zasady - dowody w sprawie ustalenia prawa do zasiłku celowego zbierane są w trakcie rodzinnego wywiadu środowiskowego, w trakcie którego osoby z którymi jest on przeprowadzany okazują dokumenty na okoliczność ustalanej sytuacji materialnej, zdrowotnej czy też rodzinnej. Gromadząc materiały dowodowe w sprawie organ administracji publicznej winien mieć na względzie, że w postępowaniu administracyjnym stoi na straży praworządności, co zobowiązuje go do powiadomienia organów ścigania o ewentualności popełnia czynu karalnego zawsze wtedy, gdy istnieje prawdopodobieństwo, że przedłożone przez stronę dokumenty są fałszywe.

\section{Rozstrzygnięcie w sprawie przyznania zasiłku celowego na zaspokojenie niezbędnej potrzeby bytowej}

Podjęcie rozstrzygnięcia w sprawie przyznania zasiłku celowego na zaspokojenie niezbędnej potrzeby bytowej poprzedza dokonana przez właściwy organ ocena zebranego materiału dowodowego w sprawie. Dokonując tej oceny organ może jednym dowodom przyznać przymiot wiarygodności i uznać je za istotne dla rozstrzygnięcia sprawy, a inne może uznać za niewiarygodne. Możliwe jest zatem stwierdzenie przez organ właściwy w przedmiocie przyznania zasiłku celowego dysproporcji zachodzącej pomiędzy udokumentowaną wysokością dochodu osoby, której potrzeba bytowa ma zostać zaspokojona, a sytuacją majątkową tej osoby. Dysproporcja może wskazywać, że osoba ubiegająca się o świadczenie z zakresu pomocy społecznej ma możliwość samodzielnie przezwyciężyć życiowe trudności. Sytuacja taka dotyczy np. sytuacji, gdy osoba, pomimo niskich dochodów, posiada znaczne oszczędności lub inne zasoby finansowe, wartościowe przedmioty majątkowe czy nieruchomości (Sierpowska, 2014, s. 117 i nast.).

W orzecznictwie wskazuje się, że świadczenia z pomocy społecznej nie są bezwzględnym uprawnieniem przysługującym każdemu, kto wystąpi o taką pomoc. Spośród wielu potrzebujących, wybór najbardziej legitymowanych do pomocy ze środków budżetowych, należy bowiem do organu. Zgodnie z art. 4 u.p.s. osoby i rodziny korzystające z pomocy społecznej są obowiązane do współdziałania w rozwiązywaniu ich trudnej sytuacji życiowej, co oznacza, że świadczenia pieniężne z pomocy społecznej powinno zostać przyznawane dopiero w przypadku wykorzystania przez wnioskodawcę własnych zasobów, uprawnień i możliwości (Wyrok WSA w Warszawie z 29.05.2018). Celem pomocy społecznej jest bowiem wspieranie, a nie wyręczanie osób i rodzin w ich wysiłkach zmierzających do zaspokojenia niezbędnych potrzeb życiowych oraz umożliwienie im bytowania w warunkach odpowiadających godności człowieka. Pomoc państwa ma zatem charakter subsydiarny, tj. dopuszcza się interwencję 
tylko w takich przypadkach, gdy osoba lub rodzina rzeczywiście nie ma możliwości samodzielnego przezwyciężania trudności życiowych. W sytuacji więc, gdy stan majątkowy osoby, której potrzeba bytowa ma być zaspokojona wskazuje, iż jest w stanie przezwyciężyć trudną sytuację życiową, wykorzystując własne zasoby, uzasadniona jest odmowa przyznania wnioskowanego świadczenia (Wyrok WSA w Poznaniu z 31.07.2019; Wyrok WSA w Łodzi z 29.01.2019; Wyrok WSA w Gliwicach z 3.06.2014).

Podnieść należy również, że cecha regularności dyskwalifikuje daną potrzebę bytową jako wymagającą zaspokojenia za pomocą środków publicznych. Tylko bowiem element zaskoczenia osoby zainteresowanej biegiem wydarzeń może tworzyć przesłankę niezbędności, o której mowa w art. 39 ust. 1 u.p.s. Powtarzalność powstającej potrzeby bytowej uchyla zatem cechę niezbędności. Skorzystanie więc - poprzez zasiłek celowy na zaspokojenie niezbędnej potrzeby bytowej - ze środków publicznych zobowiązuje uprawnionego do samodzielnego zapobiegania powstawaniu analogicznych potrzeb w przyszłości pod rygorem uznania, iż w przyszłości tożsama potrzeba bytowanie będzie miała cechy niezbędności (Maciejko, 2013, s. 177-178).

W odniesieniu do rozstrzygnięcia w przedmiocie prawa do zasiłku celowego na zaspokojenie niezbędnej potrzeby bytowej zwraca się uwagę na fakultatywny charakter tego świadczenia. Fakultatywny charakter zasiłku celowego oznacza, że organ może, ale nie musi go przyznać w przypadku ustalenia, że występują przesłanki wymienione w art. 39 ust. 1 u.p.s. (Wyrok NSA z 28.04.2020; Wyrok WSA w Krakowie z 7.01.2020). Rozstrzygnięcie w przedmiocie tego zasiłku ma zatem charakter uznaniowy, a w związku z tym organ - po dokonaniu oceny całokształtu sytuacji życiowej, bytowej i majątkowej osoby, której potrzeba ma zostać zaspokojona - może, ale nie musi przyznać, wnioskowanej pomocy (Wyrok WSA w Opolu z 22.10.2019; Wyrok WSA w Poznaniu z 17.10.2019; Wyrok WSA w Szczecinie z 10.10.2019; Wyrok WSA w Gliwicach z 8.08.2019). Nadto w orzecznictwie wskazuje się, że jeżeli organ przyznaje świadczenie pieniężne z pomocy społecznej to jego wysokość determinowana jest wielkością środków finansowych będących w dyspozycji tego organu, które mają stanowić pokrycie na wsparcie wszystkich potrzebujących spełniających ustawowe kryteria do uzyskania pomocy (Wyrok NSA z 6.12.2019; Wyrok WSA w Rzeszowie z 30.10.2019). Żaden przepis u.p.s. nie określa bowiem wysokości zasiłku celowego na zaspokojenie niezbędnej potrzeby bytowej, ani też kryteriów ustalenia jego wysokości, pozostawiając w tym zakresie organowi działanie w granicach uznania administracyjnego. W orzecznictwie przyjmuje się, że wyznacznikami ustalania wysokości zasiłku celowego są z jednej strony sytuacja materialna wnioskodawcy i cel, na który zasiłek jest przyznawany, a z drugiej strony - możliwości finansowe organów pomocy społecznej (Wyrok WSA w Łodzi z 12.02.2019; Wyrok WSA w Łodzi z 21.05.2019). Oznacza to, że zasiłek celowy na zaspokojenie niezbędnej potrzeby bytowej może zostać przyznany w niższej wysokości niż oczekiwana przez stronę.

Rozstrzygnięcie w sprawie przyznania zasiłku celowego na zaspokojenie niezbędnej potrzeby bytowej następuje w formie decyzji administracyjnej (u.p.s., art. 106, ust.1). Decyzją tą - co do zasady - jest albo decyzja o przyznaniu zasiłku celowego, albo decyzja o odmowie przyznania tego zasiłku. Decyzja w przedmiocie przyznania zasiłku celowego na zaspokojenie niezbędnej potrzeby bytowej powinna zawierać elementy określone w art. 107 k.p.a., w tym również uzasadnienie. Uzasadnienie faktyczne decyzji - jak wskazano w art. 107 par. 3 k.p.a. - powinno w szczególności zawierać wskazanie faktów, które organ uznał za udowodnione, dowodów, na których się oparł, oraz przyczyn, z powodu których innym dowodom odmówił wiarygodności i mocy dowodowej, zaś uzasadnienie prawne - wyjaśnienie podstawy 
prawnej decyzji, z przytoczeniem przepisów prawa. Wskazać należy zatem, że - jak podnosi się w orzecznictwie sądowoadministracyjnym - organy administracji publicznej orzekające w sprawach świadczeń z pomocy społecznej powinny w uzasadnieniu decyzji podać konkretnie wysokość kwoty jaką dysponowały na udzielenie danego rodzaju pomocy, jaka kwota została już rozdysponowana i w jakiej wysokości były przyznawane przeciętne świadczenia. Nadto w decyzji winno znaleźć się należyte uzasadnienie - w odniesieniu do konkretnej sytuacji życiowej i majątkowej wnioskodawcy - wysokości przyznanego zasiłku celowego, zwłaszcza jeżeli wysokość przyznanego świadczenia jest bliska minimum. W przypadku wydawania decyzji w ramach uznania administracyjnego, a taką jest decyzja w przedmiocie zasiłku celowego na zaspokojenie niezbędnej potrzeby bytowej, organy administracji publicznej mają bowiem obowiązek szczególnej dbałości o prawidłowe i wyczerpujące uzasadnienie podjętego rozstrzygnięcia (Wyrok WSA w Warszawie z 14.11.2013).

\section{Podsumowanie}

Analiza regulacji normujących możliwość przyznania zasiłku celowego na zaspokojenie niezbędnej potrzeby bytowej uzasadnia wniosek, że jest to świadczenie, którego istota sprowadza się do usunięcia stwierdzonego deficytu w zakresie konkretnej potrzeby bytowej. Zasiłek celowy nie jest zatem - co podnoszone jest również w orzecznictwie sądowoadministracyjnym - świadczeniem nakierowanym na aktywizację wnioskodawcy w takim znaczeniu, że jego wysokość nie może być determinowana zakresem działań podjętych przez niego w celu zdobycia środków na zaspokojenie danej potrzeby (Wyrok WSA w Rzeszowie z 11.03.2020). Jednocześnie cecha regularności dyskwalifikuje daną potrzebę bytową jako wymagającą zaspokojenia za pomocą środków publicznych, gdyż wyłącznie element zaskoczenia osoby zainteresowanej biegiem wydarzeń może tworzyć ustawową przesłankę niezbędności danej potrzeby. To zaś oznacza, iż zasiłek celowy na zaspokojenie niezbędnej potrzeby bytowej z założenia jest świadczeniem jednorazowym przyznawanym w szczególnych okolicznościach, których wnioskodawca nie mógł przewidzieć. Zauważenia wymaga przy tym, że dopuszczalne jest, a w praktyce stanowi to raczej regułę, zaspokajanie w formie zasiłku celowego więcej niż jednej potrzeby osoby zainteresowanej. To zaś oznacza, że świadczenie to może znacząco zmienić sytuację osoby potrzebującej. W konsekwencji np. przyznania zasiłku celowego na zakup komputera następuje istotna zmiana sytuacji osoby zainteresowanej w zakresie dostępu do oferty edukacyjnej, gdyż narzędzie to często jest niezbędne do jej prowadzenia. Zapewnienie zatem dostępu do dobra jakim jest komputer oznacza w tym przypadku, iż zasiłek celowy stanowi skuteczne narzędzie w walce z wykluczeniem społecznym w obszarze dostępu do lepszej edukacji.

Analiza przepisów regulujących przyznanie zasiłku celowego na zaspokojenie niezbędnej potrzeby bytowej uzasadnia zaś twierdzenie, iż tryb w jakim przyznawane jest to świadczenie - choć przyjmuje postać sformalizowanego postępowania jurysdykcyjnego - uwzględnia ewentualne ułomności osoby znajdującej się w niezbędnej potrzebie bytowej. Mając bowiem na uwadze, że osoby potrzebujące wsparcia w tej formie często są przewlekle chore, niepełnosprawne, czy niezaradne, ustawodawca dopuścił możliwość uruchomienia postępowania w przedmiotowej sprawie nie tylko na wniosek osoby zainteresowanej, ale także z inicjatywy osoby trzeciej, jak również z urzędu. Nadto aktywność osoby zainteresowanej w postępowaniu w przedmiocie przyznania zasiłku celowego sprowadza się w zasadzie do współdziałania z pracownikiem socjalnym przeprowadzającym rodzinny wywiad środowiskowy, a współ- 
praca w tym zakresie ogranicza się do rzetelnego przedstawienia sytuacji osobistej, rodzinnej, dochodowej i majątkowej oraz okazania wymaganych dokumentów. Korzystnie ocenić należy również przyjęte przez ustawodawcę rozwiązanie dotyczące wysokości przyznanego zasiłku celowego. Wysokość wnioskowanego świadczenia jest determinowana bowiem zarówno ustaleniami poczynionymi przez pracownika socjalnego w trakcie rodzinnego wywiadu środowiskowego, jak również wielkością środków finansowych będących w dyspozycji danego organu. Podejmowanie przez organ rozstrzygnięcia w granicach uznania administracyjnego ma stanowić zatem gwarancję, że organ - w granicach budżetu jakim dysponuje - udzieli wsparcia każdej z osób potrzebujących, choć wsparcie to może być niższe niż oczekiwane. W rezultacie poczynionych rozważań skonstatować należy, iż procedura uzyskania zasiłku celowego ukształtowana została w sposób, który może być postrzegany jako skuteczny mechanizm przeciwdziałający wykluczeniu społecznemu.

\section{Literatura}

Frąckowiak, R., Górna, R., Kopania, R., Krajewski, T., Lisowski, A., Sarna, M., Szochner-Siemińska, M. (2019). Ustawa o pomocy społecznej. Komentarz. Warszawa: C. H. Beck.

Golinowska, S., Broda-Wysocki, P. (2005). Kategorie ubóstwa i wykluczenia społecznego. Przegląd ujęć. W: S. Golinowska, E. Tarkowska i I. Topińska (red.). Ubóstwo i wykluczenie społeczne. Badania. Metody. Wyniki (s. 17-54). Warszawa: IPPIS.

Jaśkowska, M., Wilbrandt-Gotowicz, M., Wróbel, A. (2020). Kodeks postępowania administracyjnego. Komentarz. Warszawa: Wolters Kluwer.

Kędziora, R. (2008). Ogólne postępowanie administracyjne. Warszawa: C. H. Beck.

Knysiak-Molczyk, H. (red.). (2015). Kodeks postępowania administracyjnego. Komentarz. Warszawa: Wolters Kluwer.

Lipowicz, I., (2013). O mądre prawo i wrażliwe państwo. Warszawa: Biuro Rzecznika Praw Obywatelskich.

Łaszczyca, G., Martysz, C., Matan, A. (2010). Kodeks postępowania administracyjnego. Komentarz. Tom I. Warszawa: Wolters Kluwer.

Małecka-Łyszczek, M. (2017). Inkluzja społeczna jako wartość w stanowieniu prawa administracyjnego na szczeblu centralnym. W: J. Zimmermann (red.). Aksjologia prawa administracyjnego. Tom I (s. 405-418). Warszawa: Wolters Kluwer.

Nitecki, S. (2012). Pomoc społeczna: procedury i tryb przyznawania świadczeń. Wrocław: Gaskor.

Rozporządzenie Ministra Rodziny, Pracy i Polityki Społecznej z dnia 25 sierpnia 2016 r. w sprawie rodzinnego wywiadu środowiskowego, Dz.U. z 2017 r. poz. 1788.

Sierpowska, I. (2014). Pomoc społeczna. Komentarz. Warszawa: WKP.

Stopka, K. (2017). Wokół pojęcia dochodu w ustawie o pomocy społecznej. Samorzą Terytorialny, 7-8, 116-128. Ustawa z dnia 12 marca 2004 r. o pomocy społecznej, Dz. U. z 2019 r. poz. 1507 ze zm.

Ustawa z dnia 14 czerwca 1960 r. Kodeks postępowania administracyjnego, Dz. U. z 2020 r. poz. 256

Ustawa z dnia 15 kwietnia 2011 r. o działalności leczniczej, Dz.U. z 2020 r., poz. 295.

Ustawa z dnia 19 sierpnia 1994 r. o ochronie zdrowia psychicznego, Dz. U. z 2020 r. poz. 685.

Uzasadnienie do zgłoszonego przez Radę Ministrów w dniu 4 września 2003 r. projektu ustawy o pomocy społecznej. Pobrane z: www.sejm.gov.pl (dostęp: 20.05.2020).

Woś T. (red.) (2015). Postępowanie administracyjne. Warszawa: Wolter Kluwers.

Wyrok NSA z 19.12.2016, I OSK 2186/16, LEX nr 2205303.

Wyrok NSA z 23.03.2017, I OSK 3517/15, LEX nr 2281979.

Wyrok NSA z 28.04.2020, I OSK 2360/19, LEX nr 2974107.

Wyrok NSA z 6.12.2019, I OSK 130/19, LEX nr 2865600.

Wyrok NSA z 7.03.2017, I OSK 2454/16, LEX nr 2271216.

Wyrok TK z 22 maja 2013, P 46/11, OTK-A 2013 Nr 4.

Wyrok WSA w Gdańsku z 12.04.2018, III SA/Gd 35/18, LEX nr 2483819.

Wyrok WSA w Gdańsku z 22.09.2010, II SA/Gd 364/10, LEX nr 752471. 
Wyrok WSA w Gliwicach z 22.07.2014, IV SA/GI 1022/13, LEX nr 1520784.

Wyrok WSA w Gliwicach z 3.06.2014, IV SA/GI 839/13, LEX nr 1476783.

Wyrok WSA w Gliwicach z 8.08.2019, II SA/GI 566/19, LEX nr 2719213.

Wyrok WSA w Gorzowie Wielkopolskim z 20.11.2019, II SA/Go 485/19, LEX nr 2745253.

Wyrok WSA w Kielcach z 19.09.2018, II SA/Ke 280/18, LEX nr 2565981.

Wyrok WSA w Kielcach z 22.01.2020, II SA/Ke 891/19, LEX nr 2781929.

Wyrok WSA w Krakowie z 7.01.2020, III SA/Kr 1107/19, LEX nr 2766593.

Wyrok WSA w Lublinie z 6.03.2018, II SA/Lu 1075/17, LEX nr 2560297.

Wyrok WSA w Łodzi z 23.10.2008, III SA/Łd 164/08, LEX nr 510332.

Wyrok WSA w Łodzi z 20.06.2018, II SA/Łd 353/18, LEX nr 2518684.

Wyrok WSA w Łodzi z 11.06.2019, II SA/Łd 314/19, LEX nr 2693095.

Wyrok WSA w Łodzi z 12.02.2019, II SA/Łd 1097/18, LEX nr 2627674.

Wyrok WSA w Łodzi z 21.05.2019, II SA/Łd 1131/18, LEX nr 2676839.

Wyrok WSA w Łodzi z 29.01.2019, II SA/Łd 886/18, LEX nr 2625895.

Wyrok WSA w Opolu z 13.05.2014, II SA/Op 136/14, LEX nr 1474143.

Wyrok WSA w Opolu z 22.10.2019, II SA/Op 288/19, LEX nr 2739300.

Wyrok WSA w Poznaniu z 17.10.2019, IV SA/Po 484/19, LEX nr 2732033.

Wyrok WSA w Poznaniu z 2.10.2019, II SA/Po 334/19, LEX nr 2729684.

Wyrok WSA w Poznaniu z 29.05.2018, II SA/Po 1167/17, LEX nr 2510068.

Wyrok WSA w Poznaniu z 31.07.2019, II SA/Po 122/19, Lex nr 2719183.

Wyrok WSA w Rzeszowie z 11.03.2020, II SA/Rz 6/20, LEX nr 2864714.

Wyrok WSA w Rzeszowie z 30.10.2019, II SA/Rz 934/19, LEX nr 2748346.

Wyrok WSA w Szczecinie z 10.10.2019, II SA/Sz 1306/17, LEX nr 2742826.

Wyrok WSA w Szczecinie z 24.10.2019, II SA/Sz 520/19, LEX nr 2761963.

Wyrok WSA w Warszawie z 11.08.2011, II SA/Wa 1319/11, Lex nr 1086817.

Wyrok WSA w Warszawie z 14.11.2013, ISA/Wa 1579/13, LEX nr 1406407.

Wyrok WSA w Warszawie z 23.03.2017, I SA/Wa 346/17, LEX nr 2276508.

Wyrok WSA w Warszawie z 29.05.2018, I SA/Wa 1874/17, LEX nr 2550926.

Wyrok WSA we Wrocławiu z 14.05.2019, IV SA/Wr 19/16, LEX nr 2678797.

Wyrok WSA we Wrocławiu z 14.06.2019a, IV SA/Wr 151/19, LEX nr 2700087.

Wyrok WSA we Wrocławiu z 14.06.2019b, IV SA/Wr 152/19, Lex nr 2700409.

Wyrok WSA we Wrocławiu z 14.06.2019c, IV SA/Wr 153/19, LEX nr 2700426.

Wyrok WSA we Wrocławiu z 21.05.2019, IV SA/Wr 52/19, LEX nr 2685188.

Wyrok WSA we Wrocławiu z 22.02.2019a, IV SA/Wr 301/18, LEX nr 2632983.

Wyrok WSA we Wrocławiu z 22.02.2019b, IV SA/Wr 302/18 LEX nr 2632875.

\section{Designated benefit for the satisfaction of basic needs as a form of preventing social isolation}

Summary: The purpose of social service is to support the individual, and thus counteracting social isolation. Normative regulations in this regard are covered by the law of social service from the 12th of March 2004, which determines the types of benefits and the rules of impartment. One of those benefits is the designated benefit for basic needs. In the article, the ponderation has been done about if the designated benefit is a successful tool against social isolation. Thereupon, the normative regulations which determine the appropriation and form of this benefit have been analyzed and presented. This analysis concludes that the institution of the designated benefit for basic needs, which functions in the Polish legal system, could be perceived as an effective mechanism that counteracts social isolation.

Keywords: social service, financial support of the citizens by the country, poverty prevention, designated benefit for the necessary satisfaction of needs,-cash benefit

JEL codes: J65, H55 


\section{Informacje o autorach}

\section{Katarzyna Małysa-Sulińska}

ORCID: 0000-0002-6406-8851

Katedra Prawa Samorządu Terytorialnego

Wydział Prawa i Administracji

Uniwersytet Jagielloński

ul. Bracka 12, 31-005 Kraków

e-mail:k.malysa-sulinska@uj.edu.pl
Anna Kawecka

SKO w Krakowie

ul. J. Lea 10, 30-048 Kraków

sko@kolegium.krakow.pl

\section{Prawa autorskie i licencja / Copyright and License} (c) $(1) \Theta$
Publikacja na licencji Creative Commons Uznanie autorstwa -

Użycie niekomercyjne - Bez utworów zależnych 4.0 Międzynarodowe (CC BY-ND 4.0) http://creativecommons.org/licenses/by-nc-nd/4.0/deed/pl

This work is published under the terms of the Creative Commons Attribution - NoDerivetives International (CC BY-ND 4.0) License http://creativecommons.org/licenses/by-nc-nd/4.0

Wydane przez Uniwersytet Ekonomiczny w Krakowie. Małopolska Szkoła Administracji Publicznej

Published by Cracow University of Economics - Krakow, Poland. Małopolska School of Public Administration of the Cracow University of Economics 